\title{
Design Framework and Principles for Learning Environment Co-Design: Synthesis from Literature and Three Empirical Studies
}

\author{
Tiina Mäkelä ${ }^{1, *}$ and Teemu Leinonen ${ }^{2}$ \\ 1 Finnish Institute for Educational Research, University of Jyväskylä, P.O. Box 35, FI-40014 University of \\ Jyväskylä, Finland \\ 2 School of Arts, Design and Architecture, Aalto University, P.O. Box 11000, FI-00076 Aalto, Finland; \\ teemu.leinonen@aalto.fi \\ * Correspondence: tiina.m.makela@jyu.fi
}

Citation: Mäkelä, T.; Leinonen, T. Design Framework and Principles for Learning Environment Co-Design: Synthesis from Literature and Three Empirical Studies. Buildings 2021, 11, 581. https://doi.org/10.3390/ buildings11120581

Academic Editors: Pamela Woolner and Paula Cardellino

Received: 13 October 2021

Accepted: 22 November 2021

Published: 25 November 2021

Publisher's Note: MDPI stays neutral with regard to jurisdictional claims in published maps and institutional affiliations.

Copyright: (c) 2021 by the authors. Licensee MDPI, Basel, Switzerland. This article is an open access article distributed under the terms and conditions of the Creative Commons Attribution (CC BY) license (https:// creativecommons.org/licenses/by/ $4.0 /)$.

\begin{abstract}
The need for environments conducive to learning and wellbeing has been broadly recognised. Considering particularly learner perceptions in the learning environment design is known to improve both their learning and wellbeing. There are no, however, shared theoretical frameworks guiding the learning environment co-design from the learner perspective. As a response to this challenge, a learning environment design (LED) framework was developed based on the literature and co-design involving learners aged 7 to $19(n=342)$ in Finland $(n=266)$ and Spain $(n=76)$. The LED framework entails 53 characteristics grouped under seven constructs. It draws attention to the importance of balancing communality with individuality, comfort with health, and novelty with conventionality. Flexibility and functionality are recognised as central enablers for a quality learning environment. The study suggests a design framework and principles for learning environment co-design. They can serve as a research-based introduction to the topic after which priorities can be defined based on the concrete design target and goals, and concrete design solutions can be created in the participatory design involving learners and other key stakeholders.
\end{abstract}

Keywords: design framework; design principles; educational design research; learning and wellbeing; learning environments; participatory design; co-design

\section{Introduction}

In recent years, there has been a growing interest in reconsidering the design of educational spaces and environments. The need to design environments conducive to learning and wellbeing has been broadly recognised. For instance, Learning Environments Evaluation Programme (LEEP) by the Organisation for Economic Co-operation and Development (OECD) was created to support the development of environments leading to "improved education, health, social and well-being outcomes" [1].

There is already a strong body of research representing the field of education (e.g., [2]), health science (e.g., [3]), environmental science (e.g., [4]), and architecture (e.g., [5]) contributing to identifying learning environment characteristics supporting both learning and wellbeing. Earlier research has emphasised the importance of social relations, individualisation [6], pleasantness, physical wellness [7], novel and conventional tools and spaces [8], and flexibility and functionality [9]. Different aspects of learning environments, such as psychosocial, physical, and technological are, however, most commonly studied separately [10-12].

Byers and colleagues [13] argue that it is vital to assure that environments support high quality teacher-student interactions and that pedagogy (e.g., interactive instruction), space (e.g., student-centric space), and use of technologies (e.g., tablet PCs) are aligned. A similar attempt towards more holistic visions can be found in a study by López Costa [14] considering an environmental, pedagogical, and digital-technological dimension in the integration 
of digital devices in early childhood, primary, and secondary school environments. Studies by Barrett and colleagues [7,15], in turn, have identified a holistic impact of naturalness (light, sound, temperature, air quality, and links to nature), individualisation (ownership, flexibility, and connection), and appropriate level of stimulation (complexity and colour) on learning. Likewise, López-Chao and colleagues $[16,17]$ have identified relationships between learning outcomes and variables such as ventilation, artificial light, noise, Wi-Fi coverage, room size, ergonomics, and connection with nature. Further, López-Chao and López-Pena [18] found that academic results are influenced by the place attachment, the classroom design as a facilitator of social interaction, social interaction in learning, and the satisfaction of indoor environmental quality.

Despite these efforts towards a more holistic understanding of the influence of different learning environment dimensions on learning and wellbeing, research knowledge seems not to transfer well to frameworks and principles that can guide the learning environment design process and designers.

The importance of considering particularly learner (pupil or student) perception in the learning environment design process is supported by the research indicating that the congruence between learners' perception of preferred and experienced environments can impact learning positively [2]. The approach is also supported by learner-centred pedagogies promoting learners' agency in a learning process [19]. However, studies on learners' opinions seem not to provide useful frameworks that designers and architects could use in the school design process [10], nor do they commonly gather learner perceptions on environments fostering both learning and wellbeing. The few studies looking at learners' views from both learning and wellbeing perspectives are small-scale qualitative studies (e.g., $[8,20])$. They also commonly lack a broader theoretical framework [5] and therefore the results are difficult to apply to different sociocultural contexts. Participatory design (PD) projects may, therefore, remain isolated and experimental and lack both sustainability and scalability [21]. On the other hand, there is research on school architecture that is focusing on the architecture itself, not on the activity taking place in the space. For instance, Gislason ([12], p. 127) has criticised that research on school architecture typically considers "teaching and learning apart from architectural settings" or studies are centred on "the built environment separately from classroom practices".

This study responded to the identified demand to develop theoretically and practically significant, empirically tested learning environment design (LED) framework to support the participatory (re)design of environments conducive to learning and wellbeing. The study merges perspectives from various theories and disciplines and creates a framework to support the participatory co-design of environments fostering learning and wellbeing based on the research literature and empirical studies involving learners representing different age groups (from 7 to 19 years), genders, and cultural contexts, Finland and Spain, in the design process. The aim was to create a framework which supports balancing the use of previous theoretical insights and research-based know-how with learners' voice in co-design initiatives. The following research questions were set:

- Q1: What kind of structure can be identified as optimal for the LED framework?

- Q2: What are the relevant learning environment characteristics of the LED framework based on learners' views?

In this article, we start by defining the theoretical background of this study. We proceed by presenting the research design with methodological approach and data collection. After presenting the empirical results, in discussion, we propose substantive, i.e., content-related, design principles formulated for co-designing learning environments based on the study and also supported by other studies in this field.

The study is a synthesis of three sub-studies [22-24] which were also part of doctoral dissertation in educational science [25]. Unlike the previous publications, this article synthesises and conceptualises the results in order to also contribute to design research and practice. This article focuses on presenting the overview of the framework development based on the literature and shared views amongst the learners representing different 
sociocultural contexts and educational levels. More detailed description of each sub-study, research instruments, and analysis can be found in the published sub-studies.

\section{Theoretical Background}

Guided particularly by Dewey's $[26,27]$ educational philosophy, the study aimed at capturing learning environment characteristics fostering highly interconnected cognitive, emotional, social, and physical dimensions of learning and wellbeing (see also $[8,28]$ ). In line with Dewey [26,27], sociocultural and socioconstructivist paradigms inspired by authors such as Vygotsky [29], and the ecological model of Bronfenbrenner [30], individual and social human activities (i.e., psychosocial environments) are seen as highly interconnected with physical environments. Further, Dewey's [27] descriptions of timeor space-wise immediate and remote environments were connected with more recent considerations of technology-enhanced learning and virtual-physical or hybrid environments [31-34].

In this research, learning environments are conceptualised as complex, closely interconnected psychosocial and technology-enhanced physical and virtual environments [25]. Therefore, the object of design in a case of learning environment is not only the physical and virtual spaces and tools, but also individual and social human activities, that is, policies, practices, services, interactions, etc. connected with the spaces and tools (see also [35]). In this research, the attention is particularly at the microsystem level (immediate environment), but mesosystem linking, e.g., home and school environments, and wider societal and cultural environments are also considered (see [30,36]). In line with Dewey [26,27], individuals are viewed to be in dynamic interaction with their social and (technology-enhanced) physical environments; while these environments can promote, permit, or hinder human activities, individuals and groups can also actively influence them.

A literature review [25] was conducted prior to empirical studies towards the construction of a preliminary conceptual framework (Version 1.0, i.e., V1.0). The aim was to identify learning environment characteristics frequently presented in the literature and to construct a conceptual understanding of key characteristics of environments conducive to learning and wellbeing. Various electronic databases (e.g., ERIC, Google Scholar, JSTOR, and ScienceDirect) were used. The most frequent keywords were "physical or psychosocial or technology-enhanced learning environment(s)", "classroom or school or educational environment(s)", "school design or architecture", and "learning spaces". Keywords were used both separately and in various combinations. They were also combined with the keywords "learning" and "wellbeing". The literature studied represented various disciplines, mainly educational and architectural studies but also studies in the field of computer science, environmental psychology, and health sciences. It included theoretical and empirical literature and both qualitative and quantitative studies. There were studies involving learners, and studies involving various stakeholders and studies not involving any stakeholders in the design. Earlier literature reviews were also examined. Initially, around 150 publications were selected based on their relevance in general (e.g., number of citations) and their relevance in relation to the research objectives. Of these publications, 55 were selected for a more in-depth analysis.

The main learning environment characteristics of the conceptual framework V1.0 guiding the study were divided into the following three partially overlapping constructs: (I) overall wellbeing, (II) learning situation, and (III) learning tools and space design (Figure 1). The three constructs identified based on the literature have similarities with Cohen's [28] considerations of school climate consisting of physical and social-emotional safety, relationships (cf., wellbeing), teaching and learning (cf., learning situations), and external environment (cf., learning tools and space). 


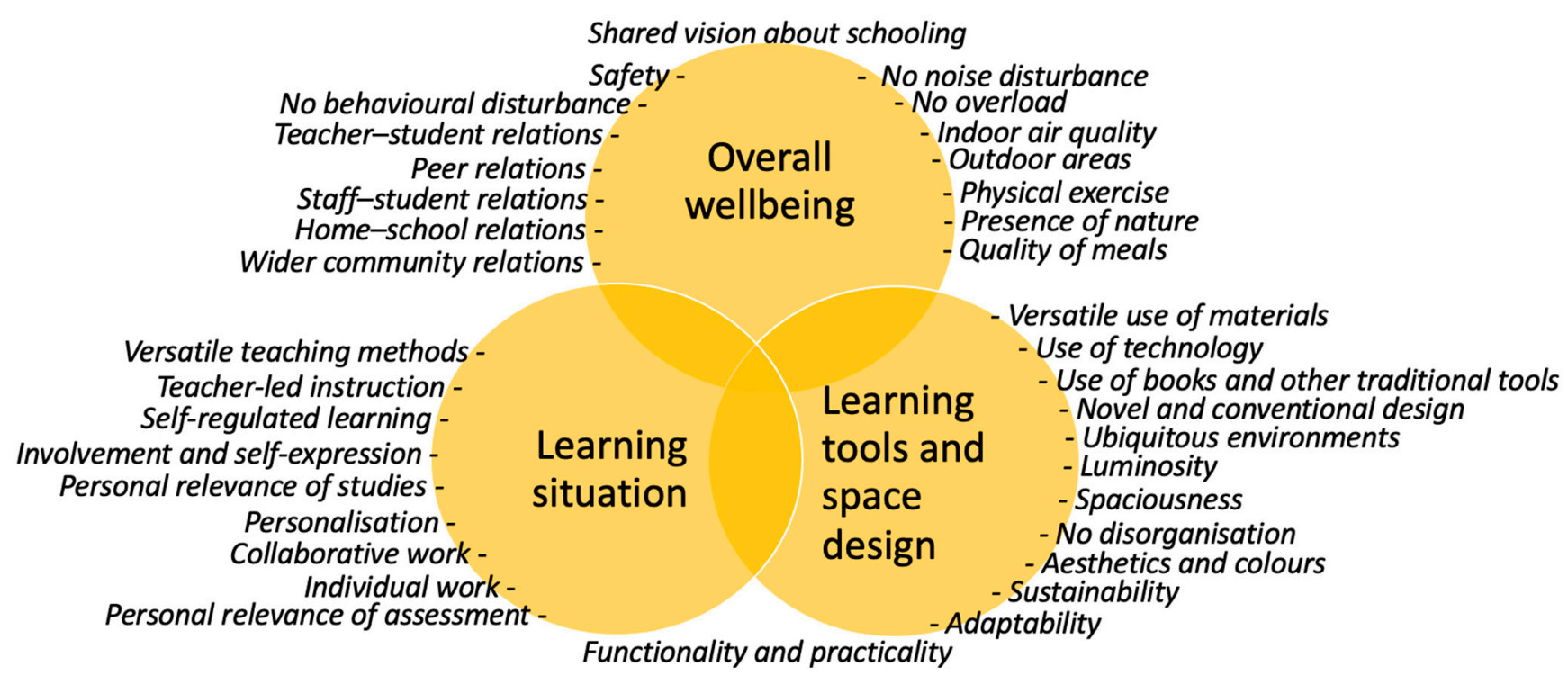

Figure 1. Learning environment design (LED) framework V1.0: Constructs and characteristics selected based on the literature review (Example literature, see [2-12,20,33,34,37-67]).

\section{Research Design and Procedure}

The methodological approach in this study is one branch of design research (cf. e.g., design research described by Luck [35]) labelled "educational design research" [68]. It focuses on the design in education and intertwines educational planning, practice, and theory development. The approach includes design experiments [69,70], developmental research [71], and design-based research [72]. As typical for such approaches [72], this study aimed at theoretically significant contributions by creating a framework, whose content and construct validity is tested in empirical studies. The study was also guided by the principles of pragmatism and practicality [70,73]: research know-how was employed in the actual learning environment design process during the study and can be used in the future (external validity). In addition to the LED framework development, the aim was to formulate substantive, that is, content-related design principles [68] that can serve as guidelines in the future design.

The aim was that the framework developed and tested in various contexts balances both fixed and emerging elements, thus allowing both contextualisation and generalisation between contexts $[69,74,75]$. The study consisted of iterations, with each iteration considered a semi-independent research cycle leading to progressive improvement of the design framework [76-78]. A mixed-methods approach was employed $[69,79]$ by embedding statistical methods within predominantly qualitative research. Finally, as typical to educational design research $[75,76,80]$, various stakeholders were involved in the design research. The focus was, however, particularly on gathering learning environment characteristics relevant for learners.

In relation to the learner participation, the present educational design research utilised some aspects of the participatory design (PD) approach. This approach has commonly been employed in the design of physical learning environments [38,81-83]. It has also been employed in instructional design [84] and in the design of educational technology [85]. PD has been used to combine perceptions of designers, teachers, and learners [86] as well as other school staff members, parents, and the wider community [87], including, e.g., policymakers, local authorities, and contractors [88].

$\mathrm{PD}$ is in line with learner-centred educational views honouring learners' epistemological agency $[19,26,27]$. Similar ideas have also been expressed in approaches involving learners as (co)researchers [89] and those focusing on learners' voices [90-92]. Concepts "participatory design" and "co-design" are used in this study in a broad sense to refer to knowledge sharing and creation (in relation to the past, present, and future) between 
participants representing various backgrounds [93]. Smith and Iversen [21] emphasise the importance of carefully defining the relationships and forms of participation for each stakeholder group. In this study, learner involvement was particularly important so as to see what learning environment characteristics they considered as relevant to their learning and wellbeing. By combining previous research literature with empirical studies focusing on learners' perceptions, the aim was to create a framework whose validity was confirmed by learners.

Figure 2 summarises the research cycles of this study in relation to research aims and substudies (see also [25]). Design cycles numbered as 1 to 6 refer to student (learner) involvement.

SUB-STUDY 1:

Applying framework V1.0

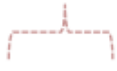

SUB-STUDY 2

Applying framework V1.0

Developing framework V2.0 and V2.1

SUB-STUDY 3:

Applying framework V2.1

Developing framework V2.2
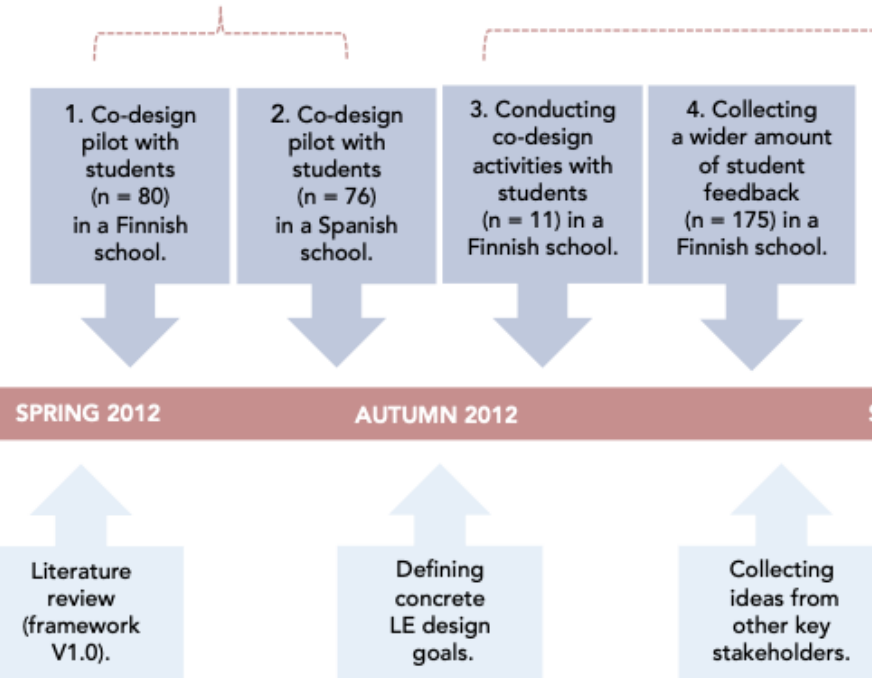

Figure 2. Design cycles in relation to sub-studies (Image by Mona Johansson in [25]).

The study aimed at rich understanding of the learners' perspectives by collecting quantitative, written, oral, and visuospatial data and analysing it with quantitative and qualitative methods (see $[21,90,94,95]$ ). The framework V1.0 was created based on the literature review (see Figure 1). Numeric and written data were collected by means of web questionnaires (sub-studies 1-3) and student feedback form (sub-study 3). Surveys contained fixed items but open questions were used for issues not raised previously. In sub-studies 1 and 2, participants elaborated physical scale models or mock-ups and in sub-study 3, virtual 3D models (see Figure 3). Visual or visuospatial methods are, however, often constrained by the participants' skills [96], they do not directly provide answers to why-questions [97] and the data may be easily misinterpreted [20]. This is why visuospatial data were combined with (semi-structured) interviews, giving participants an opportunity for explaining and presenting their work $[64,98])$. For the purpose of sub-study 3 , a type of member checking [99] was employed by inviting learners to evaluate the design proposals to assure that their insights had been interpreted correctly and considered in the design. Table 1 summarises the participants, data, and data analysis of each sub-study. For a more detailed description of the materials, see [25]. 

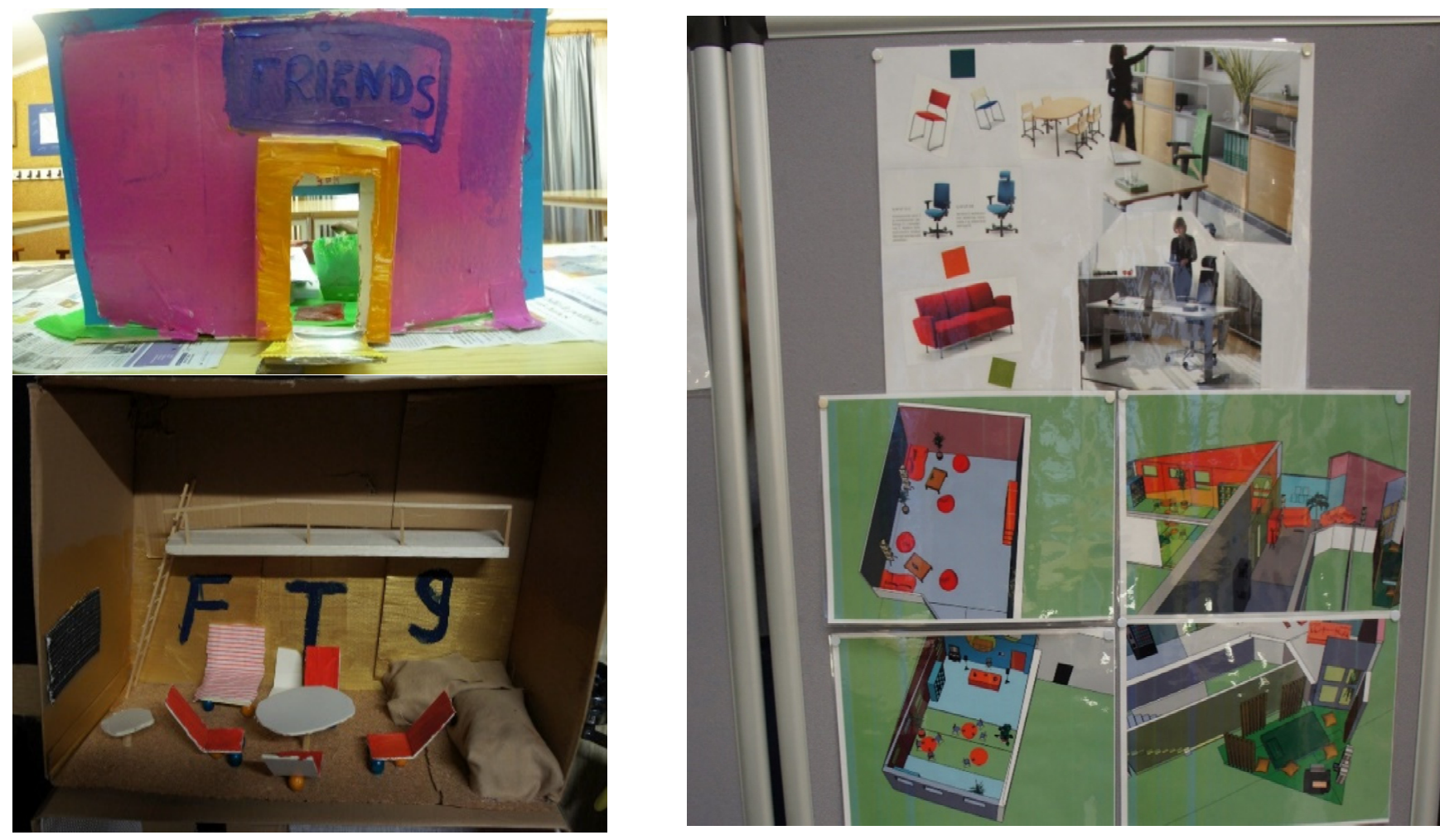

Figure 3. Examples of designs by Spanish 3rd graders (upper left), Finnish 8th graders (down left), and upper secondary school students (right).

In sub-study 1 (cycle 1), the framework V1.0 was applied in the co-design pilot sessions with learners (girls: $n=34$; boys: $n=46$ ) aged 7 to 14 years (from 2 nd grade of primary school to 2nd grade of lower secondary school) in a Finnish university-affiliated teacher training school in late spring 2012 and early autumn 2012. The web questionnaire (numeric and written data) was used as an introductory pair work activity, followed by a collaborative scale model design and group discussions. In sub-study 2 (cycles 1 and 2), the same research design was employed in co-design pilot sessions with learners aged 7 to 14 years (from 3rd grade of primary school to 3rd grade of lower secondary school) girls: $n=40$; boys: $n=36$ ) in a publicly financed private school in Spain in late autumn 2012, to test for the cross-cultural relevance and consistency of framework V1.0. An exploratory factor analysis was conducted to guide the restructuring of the initial framework with respect to theoretical constructs. Content elements (learning environment characteristics) confirmed by the quantitative and qualitative data were grouped under the renewed constructs, which were further divided into thematic sub-blocks. If the cross-analysis revealed some apparent discrepancies, a more in-depth analysis was conducted to search for their possible origin and explain them in light of the overall data. The data analysis led to the development of framework versions V2.0 and V2.1.

Sub-study 3 (cycles 3-6) was carried out in the same teacher training school in Finland where the first pilot took place. This school achieved funding for reforming some of their learning spaces. The aim was to involve upper secondary school students in the redesign of their natural science classroom and its adjacent hallway. Co-design activities (cycle 3) were part of a visual arts project course conducted during the autumn term of 2012. For their final coursework, the participating students (females: $n=8$; males: $n=3$ ) created learning environment designs consisting of 3D models/sketches and colour, furniture, and technology plan. These designs were displayed in an exhibition (cycle 4), where other students (females: $n=104$; males: $n=61$; no information on gender: $n=10$ ) had an opportunity to express their views on a structured student feedback form. Student designs and summaries of student suggestions were next presented to teachers and teacher 
students who first evaluated students' ideas and subsequently gave their own suggestions. Suggestions from all participant groups were finally communicated to the professional designers. Before implementing the changes to the actual redesign, the researchers invited participants of the co-design project course to evaluate the professional design (cycle 5). Two male upper secondary school student co-designers participated in this activity. After some final revisions, the reforms took place in summer 2013. After some months of appropriating the redesigned environments, students were invited to answer an online student satisfaction survey (females: $n=45$; males: $n=37$ ). The survey's formulation (cycle 6) was guided by the conceptual framework V2.1 but was based on the learning environment characteristics highlighted by the students in previous design cycles. The V2.2 of the framework was then constructed based on the analysis of the results of research cycles 1-6 (sub-studies 1-3).

Table 1. Participants, data, and data analysis of each sub-study.

\begin{tabular}{|c|c|c|c|}
\hline Study & Participants & Data & Data Analysis \\
\hline 1 & $\begin{array}{l}\text { Learners }(n=80) \text { age } 7 \text { to } 14 \text { years } \\
\text { in a Finnish school }\end{array}$ & $\begin{array}{l}\text { - A web questionnaire (numeric and } \\
\text { written data) } \\
\text { - Scale models/mock-ups } \\
\text { (visuospatial data) } \\
\text { - Semi-structured group discussions } \\
\text { (oral data) }\end{array}$ & $\begin{array}{l}\text { Cross-analysis of } \\
\text { - qualitative data: content analysis, } \\
\text { and } \\
\text { - quantitative data: descriptives } \\
\text { (means and standard deviation) } \\
\text { and group differences } \\
\text { (Independent-Samples t-test). }\end{array}$ \\
\hline 2 & $\begin{array}{l}\text { Learners }(n=156) \text { age } 7 \text { to } 14 \\
\text { years in a Finnish }(n=80) \text { and } \\
\text { Spanish }(n=76) \text { school }\end{array}$ & $\begin{array}{l}\text { - A web questionnaire (numeric and } \\
\text { written data) } \\
\text { - Scale models/mock-ups } \\
\text { (visuospatial data) } \\
\text { - Semi-structured group discussions } \\
\text { (oral data) }\end{array}$ & $\begin{array}{l}\text { Cross-analysis of } \\
\text { - qualitative data: content analysis, } \\
\text { and } \\
\text { - quantitative data: descriptives } \\
\text { (means and standard deviation), } \\
\text { exploratory factor analysis } \\
\text { (principal axis extraction with } \\
\text { direct oblimin rotation). }\end{array}$ \\
\hline 3 & $\begin{array}{c}\text { Learners } \\
(n=186) \text { age } 16 \text { to } 19 \text { years in a } \\
\text { Finnish school }\end{array}$ & 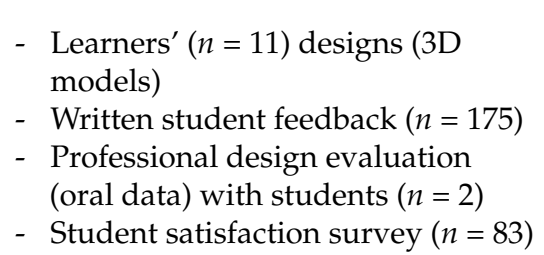 & $\begin{array}{l}\text { Cross-analysis of } \\
\text { - qualitative data: thematic analysis } \\
\text { and content analysis, and } \\
\text { - quantitative data: descriptive } \\
\text { statistics (means, standard } \\
\text { deviation, and frequencies). }\end{array}$ \\
\hline
\end{tabular}

In the Results section, we summarise the empirical results of the three sub-studies. This is followed by the discussion presenting the design principles formulated based on the sub-studies and supported by the literature.

\section{Results}

Sub-study 1 [22] employed the preliminary framework (V1.0, see Figure 1) in analysing Finnish 7- to 14-year-old learners' $(n=80)$ perceptions on environments that foster learning and wellbeing. It tested the consistency of the initial framework (construct validity) and its relevance (content validity). The focus was on participants' shared views. The three main constructs ("overall wellbeing", "learning situation", and "learning tools and space design") of the framework V1.0 were found to be valid with respect to representation of relevant learner perceptions. The three constructs appeared, however, to be highly overlapping and interrelated. In relation to framework content validity, 24 characteristics included into framework V1.0 were corroborated as the most relevant for participant learners based on the data. 
In sub-study 2 [23], the consistency and relevance of the initial framework (V1.0, Figure 1) was further explored based on the analysis of data from 7 to 14-year-old participants in both Finland $(n=80)$ and Spain $(n=76)$. Participant learners' views analysed supported cross-cultural relevance (content validity) of all characteristics included into the initial framework V1.0. In relation to framework consistency, factor analysis on the student ratings data supported restructuring of the three constructs of the initial framework into framework V2.0 with five constructs. These constructs were also subdivided in thematic clusters or sub-themes: (I) communality (social relations, teaching-learning interaction, sense of belonging, safety), (II) individuality (privacy and peacefulness, individualisation), (III) comfort (physical ease, pleasantness), (IV) health (physical wellness, no overload), and (V) versatile tools and spaces (novel tools and spaces, conventional tools and spaces, flexibility and functionality). In the data analysis, pairs of concepts of communality-individuality and comfort-health were first identified. The same idea of thematic equilibrium was also identified in two of the main themes of the fifth construct, that is, balancing novel and conventional tools and spaces. Therefore, these two themes were promoted as constructs. This left the last theme in the fifth construct, flexibility and functionality as a meta-construct that can be applied to all other constructs. A cross-analysis with other data types and theoretical, empirical, and practical considerations led to the construction of framework version 2.1. The revised framework consisted of seven constructs each divided with two to four sub-themes, and a total of 41 characteristics.

Sub-study 3 [24] aimed at testing and further developing the constructs and contents of framework V2.1 in an actual co-design project with Finnish upper secondary school students $(n=186)$ between 16 and 19 years of age. Framework V2.1 constructs were found to be feasible for this co-design project. Of the 41 characteristics included in framework V2.1, 26 characteristics were replicated, 15 characteristics were not directly replicated, and 11 characteristics emerged from this data set. The results were generally in line with the earlier sub-studies. The framework V2.2 developed based on this study cycle consisted now of 52 characteristics. In the final analysis, based on the attention participants gave to colours, aesthetics and colours were yet considered as separate characteristics (cf. Figure 1) leading to a total of 53 characteristics in the learning environment framework V3.

On a general level, learners representing different sociocultural contexts, ages, and educational levels had very shared views of environments supporting their learning and wellbeing. These general, more detailed results for each construct are presented in the following subsections.

\subsection{Communality Balanced with Individuality}

Table 2 presents four sub-themes and 14 characteristics related to communality as well as two individuality-related sub-themes and their 10 characteristics confirmed based on empirical findings of this study involving 7- to 19-year-old learners in Finland and Spain (sub-studies 1-3). In relation to communality, most of these characteristics were confirmed in at least two sub-studies. For instance, in survey responses from Finland and Spain (sub-study 2), social relations-related items received the highest ratings of all $(\mathrm{M}=4.3-4.5$ of 5). Learners considered particularly peer relations and collaborative work as important and wished, e.g., for group working spaces and furniture and good areas for socialising and spending time with peers. Further, three new characteristics, namely teacher visibility, homelike environments, and transparency emerged based on sub-study 3 involving upper secondary school students. Participants' concerns related to teacher visibility were particularly related to the plan of removing the tiered classroom floor in the redesign process. Participants also wished to have a transparent glass wall separating the classroom and the hallway. On the other hand, various characteristics were out of the scope of the specific design goals focusing on the redesign of a natural science classroom and thus were not replicated in sub-study 3.

Based on the results of sub-studies 1-3, as a whole, participant learners seemed to consider individuality-related characteristics as somewhat less important than communality- 
related characteristics (Table 2). Of these characteristics, only personal relevance of studies and individual work were amongst the most prominent 24 characteristics identified in the sub-study 1. In a survey result of sub-study 2 involving Finnish and Spanish learners, item "individual work" received the lowest ratings $(\mathrm{M}=3.4$ of 5$)$ of all survey items. In a sub-study 3 involving Finnish upper secondary school students, individual work was wished to be supported, e.g., by choosing desktops allowing individual configurations.

Table 2. Communality- and individuality-related characteristics confirmed or emerged in sub-studies.

\begin{tabular}{llll}
\hline I Communality & Sub-Study & II Individuality & Sub-Study \\
\hline (a) Social relations & & (a) Privacy and peacefulness & 2,3 \\
Teacher-student relations & 1,2 & No noise disturbance & 2,3 \\
Staff-student relations & 2 & No disorganisation & 2,3 \\
Peer relations & $1,2,3$ & No distractions & 3 \\
Home-school relations & 1,2 & Private spaces & \\
Wider community relations & 2 & & 2,3 \\
\hline (b) Teaching-learning interaction & & (b) Individualisation & 1,2 \\
Teacher-led instruction & $1,2,3$ & Personalised learning & 2 \\
Teacher visibility & 3 & Personal relevance of studies & $1,2,3$ \\
Collaborative work & $1,2,3$ & Personally relevant assessment & 2,3 \\
\hline (c) Sense of belonging & & Individual work & 3 \\
Shared vision & 1,2 & Self-regulated learning & \\
Involvement and self-expression & 1,2 & Studying during the breaks & \\
Homelike environment & 3 & & \\
\hline (d) Safety & $1,2,3$ & & \\
No behavioural disturbance & 3 & & \\
Transparency & $1,2,3$ & & \\
Physical safety & & & \\
\hline
\end{tabular}

Furthermore, personalised learning or opportunities to make choices related to one's own learning (sub-study 2) and creating various smaller-scale learning stations, enabling the selection of the working space (sub-study 3 ), were wished by the participants. In substudy 2, participants considered "reducing noise disturbance" as relevant ( $\mathrm{M}=4.1$ of 5). In sub-study 3, participants wished for concrete solutions such as good soundproofing, acoustic panels, and textiles to reduce noise. In sub-study 2, a characteristic of no distractions emerged. In sub-study 2, participants proposed, e.g., that restricting the use of the Internet may be a good way to reduce distractions. In sub-study 3, dimming curtains were wished to separate the classroom from the hallway, when in need of full concentration. Further, in sub-study 3, characteristics private spaces and areas for studying during the breaks emerged.

\subsection{Comfort Balanced with Health}

As can be seen in Table 3, the comfort construct was divided into two sub-themes comprising a total of seven characteristics and the health construct included two subthemes and eight characteristics. Comfort-related characteristics were viewed as highly important by different-aged learners participating in this study in Finland and Spain. Most of these characteristics were confirmed by all sub-studies. For instance, results of sub-study 2 indicate that in both countries, both primary and secondary school learners generally considered "spaciousness" as important $(\mathrm{M}=4.3$ of 5$)$. In the group discussions, small children explained that they wished for more space to play, whereas adolescents complained about overly cramped spaces for working.

In sub-study 2, a characteristic comfortable furniture and spaces (e.g., sofa groups and cushions) emerged. Further, characteristic no overload was divided into rest and leisure time (cf. Figure 1 and Table 3). In sub-study 3 involving Finnish upper secondary school students, a characteristic of enough seats, seating, and table space emerged. "Aesthetics" was not rated high (e.g., in sub-study 2, M = 3.6 of 5) in comparison to other items but the importance given to decorative elements of scale models indicated that participants 
valued these characteristics. Participants in all sub-studies gave lots of importance for colours. In sub-study 3, they wished for, e.g., balancing colours that are stimulating, fresh, or not depressing, with calming, not disturbing colours. Participants also proposed colourchanging lamps so as to vary colours. Presence of nature was considered as important by participants in all sub-studies (see Figure 4). For instance, gardens, park areas, presence of water (sub-studies 1 and 2), and interior plants (sub-study 3 ) were wished for.

Table 3. Comfort- and health-related characteristics confirmed or emerged in sub-studies.

\begin{tabular}{llll}
\hline III Comfort & Sub-Study & IV Health & Sub-Study \\
\hline (a) Physical ease & & (a) Physical wellness & \\
Spaciousness & $1,2,3$ & Quality of meals & 2 \\
Enough seats, tables, and table space & 3 & Indoor air quality & 2,3 \\
Comfortable furniture and spaces & 2,3 & Indoor air temperature & 3 \\
\hline (b) Pleasantness & & Ergonomics & 3 \\
Aesthetics & $1,2,3$ & Good outdoor areas & 1,2 \\
Colours & $1,2,3$ & Physical exercise & 1,2 \\
Luminosity & $1,2,3$ & (b) No overload & 2,3 \\
Presence of nature & $1,2,3$ & Rest & 2,3 \\
& & Leisure time & \\
\hline
\end{tabular}
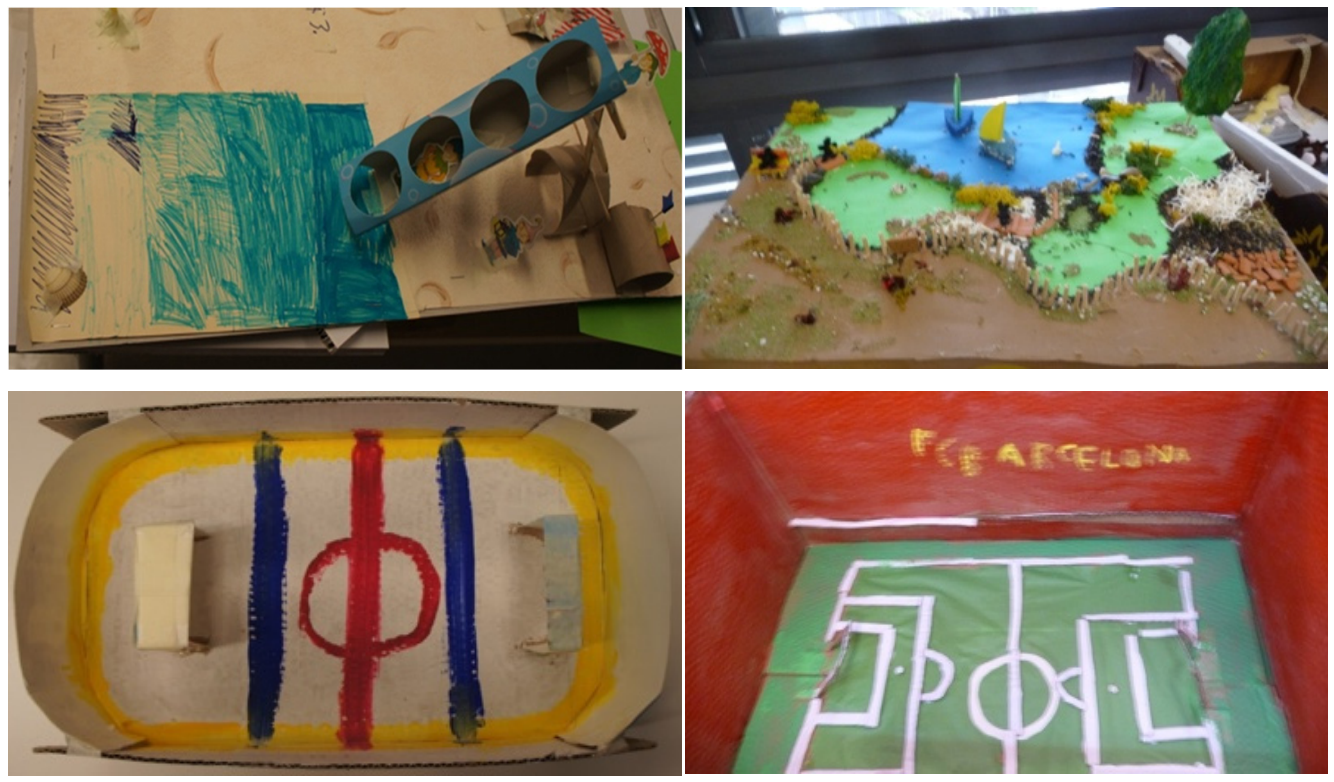

Figure 4. Learning environment design details by Finnish 2nd graders (beach), Spanish 8th graders (park), Finnish 6th graders (ice hockey rink), and Spanish 3rd graders (football stadium).

In relation to characteristics grouped under health construct, 7-14-year-old learners both in Finland and Spain rated health-related survey items as generally high $(M<4)$. Scale model constructions and group discussions revealed that learners in both countries viewed possibilities for physical exercise as important. For instance, Finnish participants paid attention to good ice hockey rinks and Spanish participants to football camps (Figure 4).

Characteristics of quality of meals, good outdoor areas, and physical exercise were not replicated in sub-study 3, possibly because they were out of the scope of the specific redesign project focusing on natural science learning environments. On the other hand, characteristics of optimal indoor air temperature and ergonomics (e.g., adjustable desks and chairs, science lab furniture) emerged based on participants' wishes. 


\subsection{Novelty Balanced with Conventionality}

As can be seen in Table 4, the five novelty-related and five conventionality-related characteristics are divided into two sub-themes. Most of the characteristics were confirmed as relevant by participant learners in sub-study 2 analysing Finnish and Spanish 7- to 14-year-old learners' perceptions. For instance, in a survey, "use of technology" and "use of books" were rated equally highly $(\mathrm{M}=4$ of 5$)$. In sub-study 2 , ubiquitous learning environment was divided into informal (e.g., beach, city), non-formal (e.g., libraries, museums, science centres), and formal (e.g., classrooms) learning environments (cf. Figure 1 and Table 4). Characteristics of informal, formal, and non-formal learning environments were not replicated in sub-study 3 as its focus was on the formal school design. On the other hand, characteristics of educational design elements (e.g., planetarium ceiling, solar system model, or colour-changing lamps for teaching colour theory) and inspiring and motivating spaces emerged in sub-study 3.

Table 4. Novelty- and conventionality-related characteristics confirmed or emerged in sub-studies.

\begin{tabular}{llll}
\hline V Novelty & Sub-Study & VI Conventionality & Sub-Study \\
\hline (a) Novel tools & & (a) Conventional tools & Use of books and other traditional \\
Use of technology & $1,2,3$ & materials & $1,2,3$ \\
Educational design elements & 3 & (b) Conventional spaces & 2 \\
\hline (b) Novel spaces & & Sustainable design & 2 \\
Informal learning environments & 2 & Non-formal learning environments & 2 \\
Novel design & $1,2,3$ & Formal learning environments & $1,2,3$ \\
Inspiring and motivating spaces & 3 & Conventional design & \\
\hline
\end{tabular}

\subsection{Flexibility and Functionality}

Finally, construct flexibility and functionality entailed four characteristics (see Table 5). In the survey results of sub-study 2 involving Finnish and Spanish learners, "versatile materials", "functionality and practicality", and "adaptability" were rated as relatively high ( $\mathrm{M}=3.8-4$ of 5$)$. In sub-study 3 , these characteristics were given an important weight by the Finnish upper secondary school students. Moreover, versatile methods emerged as a new characteristic. Participant students wished, for instance, varying learning stations both inside and outside the classroom as well as furniture allowing multiple configurations.

Table 5. Characteristics related to flexibility and functionality confirmed or emerged in sub-studies.

\begin{tabular}{ll}
\hline VII Flexibility and Functionality & Sub-Study \\
\hline Versatile use of tools and materials & $1,2,3$ \\
Versatile methods & 3 \\
Adaptability & 2,3 \\
Functionality and practicality & 2,3 \\
\hline
\end{tabular}

\section{Discussion}

The aim of this educational design research was to develop a shared design framework for co-designing psychosocial and technology-enhanced physical and virtual environments fostering learning and wellbeing. The framework was developed based on the theoretical, empirical, and practical considerations, focusing particularly on learners' perceptions. The research questions were related to the LED framework's constructs and contents. Results of this study suggest that there are specific structures that can be used to classify and gather characteristics improving learning and wellbeing when practicing co-design of learning environments. Furthermore, findings revealed several characteristics that were found relevant by learners. The framework guides particularly towards identifying the balance between communality and individuality, comfort and health, and novelty and 
conventionality, while giving flexibility and functionality a centric role in the design. To synthesise the findings from literature and the three empirical studies, it is possible to present a design framework (Figure 5) that can be utilised in design processes.

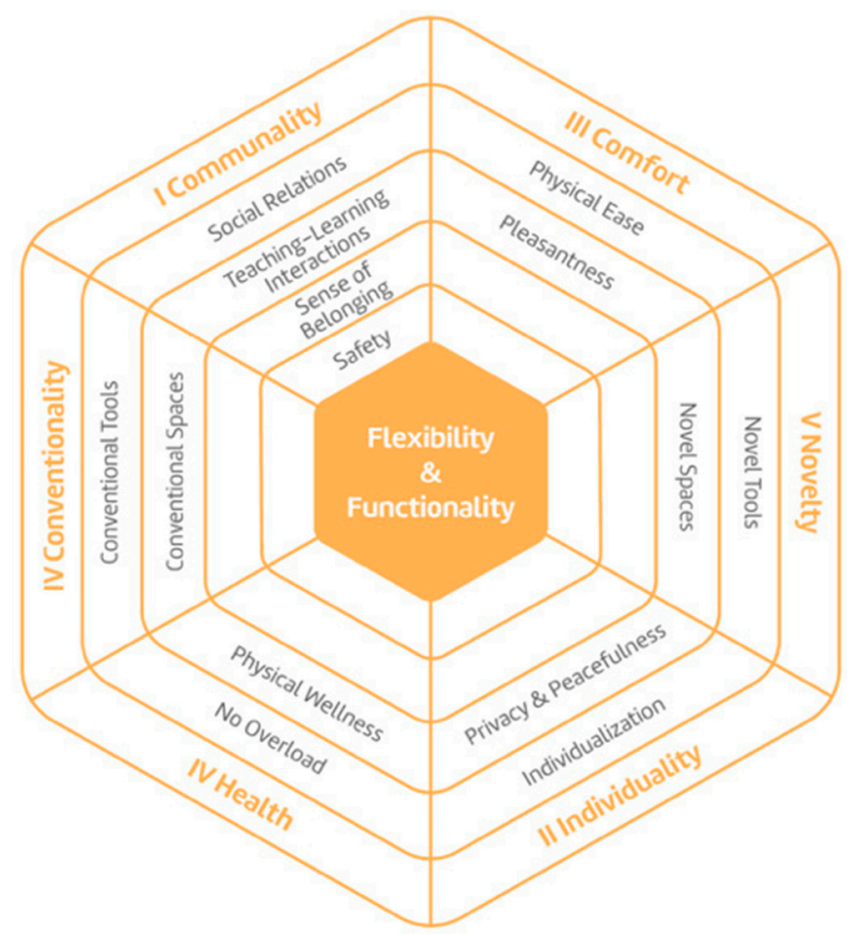

Figure 5. Visualisation of the LED framework V3 by Iconograph [100].

In relation to the LED framework constructs (Q1), to our knowledge, there are no previous frameworks that have consistently been built around the idea of maintaining equilibrium between various learning and wellbeing needs. However, some of the earlier models also consider the notion of "balancing". The pair of constructs "communality" and "individuality" are closely related to the dimensions "relationship" and "personal development" in Moos' (e.g., [101]) human environment model. Gee's [102] "humancentred design guidelines" include dimensions "communality" and "solitude". The model by Barrett and his colleagues [7] balances "open" with "private". Comfort and health, in turn, are notions typically reflected in architectural designs. Comfort, for example, was chosen as one of the main constructs in Sulonen and Sulonen's [103] characteristics, while Gee's [102] guidelines include the construct "healthful". Further, the concept of balancing novelty with conventionality is reminiscent of Moos' model's [101] dimension, "system maintenance and system change", i.e., an equilibrium between stability and responsiveness to change. The construct of "novelty" shares properties with the design principle of "stimulation", which Barrett and his colleagues ([7], p.681) described as an indicator of "the degree to which the school provides appropriate diversity (novelty)". The conventionality-construct shares similarities with the construct "durability" used in other conceptualisations $[103,104]$. Finally, the conceptual decision to place "flexibility and functionality" as the centric construct of framework is supported by both architectural $[7,38,102,103])$ and educational $[61,104]$ literature.

In relation to contents of the framework $(\mathrm{Q} 2)$, in addition to confirming the importance of each characteristic for participant learners in at least one of the three sub-studies, there is a wide body of literature confirming their relevance and transferability to various educational contexts. Example literature has already been presented in the theoretical background (see Figure 1).

In the following, we present each construct with 15 general design principles and their sub-principles that are delivered from the sub-studies 1-3 and the literature. Substantive 
design principles are formulated for each construct and learning environment characteristic. The generalisability of the design principles in other educational contexts are strengthened by research literature. The assumption is that the simultaneous design of psychosocial environments with physical and virtual environments will lead to improvements: on one hand, the individual and social human activities, practices, and services will be adequate for the designed spaces and tools. On the other hand, the designed spaces and tools will better enable the desired activities, practice, and services.

\subsection{Communality}

Principle 1: Design environments fostering good social relations.

Principle 1.1: Facilitate staff-student relations. Virtual and physical spaces should allow encounters for developing particularly good teacher-student relations (sub-studies 1 and 2; $[18,54]$ ) but also other staff-student relations (sub-study 2; [41]). These entail, e.g., the school direction [105], teaching assistants, and non-teaching staff working in the office, catering, and maintenance [41].

Principle 1.2: Support peer relations. Good peer relations can be supported by physical and virtual areas for socialising and spending time with peers (sub-studies 13; [40]). Social activity may be also encouraged by "open space and the school's compact interior" ([12], p.141). Literature (see [18]) indicates that that social interaction, particularly in relatively small groups, may be beneficial for learning.

Principle 1.3: Enable encounters with parents and other stakeholders. It is important to have time and spaces to get together and communication to promote good home-school relations (sub-studies 1 and 2; [6]) as well as to open the school to the wider community (sub-study 2; [3,50]).

Principle 2: Design environments for quality teaching-learning interaction.

Principle 2.1: Promote interaction. Collaborative work may be supported by group working tables and small and large group areas (sub-study 3; [12,65]), as well as by technological tools allowing collaboration [85]. While tiered classroom floors may support teacher-led instruction and teacher visibility (sub-study 3; $[12,49,65]$ ), they may not be recommendable as more passive presentation activities and didactic teaching should be limited [32], for instance, for introducing new topics for learners and when gradually guiding them towards more self-regulated forms of learning (see [29]). Teacher scaffolding may also be supported by novel technological tools [85]. Students may perceive both social and physical (instructions, tags, signs, labels, information boards) scaffolding as useful $[106,107]$.

Principle 3: Design environments enhancing sense of belonging.

Principle 3.1: Support creating a shared vision. Efforts need to be made to create a shared vision about schooling (sub-studies 1 and 2; [32]). Shared vision can be fostered in different gatherings, ceremonies, and celebrations both physically and virtually. Presenting school symbols on the walls may also foster shared vision [38].

Principle 3.2: Promote self-expression, involvement, and cosiness. Providing possibilities for self-expression and involvement by means of co-design (sub-studies 1-3; [94]) and creating homelike environments and inviting, welcoming, and cosy areas (sub-study $3 ;[8,10,65])$ may also enhance learners' sense of belonging and overall wellbeing. Presenting student works on the walls may foster a sense of ownership of learning space and equipment, as well as cosiness [38].

Principle 4: Design environments promoting safety.

Principle 4.1: Reduce behavioural disturbance. Behavioural disturbance such as bullying (sub-study 1), troublemaking, or vandalism (sub-study 3) may be reduced by creating pleasant environments increasing sense of ownership, belonging, and school-liking (sub-study 1-3; [38]). As argued in other studies [54], democratising classrooms, allowing for greater choice, and including the use of ICT may increase particularly adolescent students' engagement levels and positive attitudes towards schooling and school rules. 
Principle 4.2: Promote transparency of activities. Transparency and openness [7,9] can be supported by transparent surfaces, e.g., glass walls or doors (sub-study 3) and good communication design. They also augment feelings of safety [38].

Principle 4.3: Ensure safe environments for all. Physical safety (sub-study 1-3) may be promoted by increasing security (sub-studies 1 and 2; [6,81] and by designing safety working areas for experiments (sub-study 3 ). Social and physical scaffolding may also increase students' feelings of safety [106]. Safety can also be increased by assuring that it is easy to find one's way around at school [11].

\subsection{Individuality}

Principle 5: Design environments for privacy and peacefulness.

Principle 5.1: Ensure good acoustics and noise control. Noise disturbance (substudies 2 and 3; [42]) may be reduced by good soundproofing, acoustic panels, and textiles (sub-study 3). Noise disturbance may also be related to a specific type of learner behaviour [16]. For instance, while learners participating in this study representing two sociocultural contexts generally seemed to value environments free of noise disturbance, more intensive conversational style in Spain in comparison to Finland may require particularly good acoustic design.

Principle 5.2: Promote good organisation. Disorganisation (sub-studies 2 and 3; [46]) may be avoided by providing good storage spaces (sub-study 3; [108]).

Principle 5.3: Support managing possible distractions. Both pleasant and unpleasant distractions (sub-study 2; [12,34,109]) may be reduced, e.g., by restricting the use of the Internet (sub-study 2) or providing dimming curtains (sub-study 3 ) to prevent getting distracted by too much transparency. Study by López-Chao and colleagues [16] also suggest that views from the windows may cause distractions.

Principle 5.4: Provide privacy for all. The right for privacy may be supported by designing private spaces (sub-study $3 ;[32,65]$ ) and time to be and work alone. Moreover, possible age, individual, and sociocultural differences in the need for privacy should be taken into account.

Principle 6: Design environments supporting individualisation.

Principles 6.1: Create possibilities for choosing personal preferences of studying. Personalisation of learning (sub-studies 2 and 3) may be supported by creating opportunities to make choices related to one's own learning (sub-study 2; [94]) and creating various smaller-scale learning stations enabling the selection of the working space based on personal preferences (sub-study 3).

Principle 6.2: Promote personal meaningfulness of studies and assessment. Personal relevance of studies (sub-study 1 and 2) and assessment (sub-study 2) can be promoted by increasing connectedness with students' real-life aspirations [54], e.g., by means of real-life projects. Learners should be able to connect their studies also with personally relevant environments, and there should be both physical and virtual spaces where to receive personal feedback from teachers of one's progress.

Principle 6.3: Enable individual work and configuration. Individual work (substudies 1-3; [46]) requires desktops allowing individual configurations (sub-study 3). It is important to provide areas for reading, reflection, and quiet time for individual work $[3,65]$.

Principle 6.4: Support self-regulation and studying during the breaks. Self-regulated learning (sub-studies 1-3; [37]) may be fostered by providing spaces for studying during the breaks (sub-study 3) entailing spaces for informal learning outside the scheduled classes [63]. In addition, physically mediated guidance such as clear, well-structured spaces, and technological devices proving guidance to one's work may support students' self-regulation and sense of autonomy [107].

\subsection{Comfort}

Principle 7: Design environments to nurture feelings of physical ease. 
Principle 7.1: Design enough comfortable spaces and furniture for all. It is important to ensure environmental spaciousness (sub-studies 1-3; [65]) and that there are enough seats, seating, and table space for different purposes (sub-study 3; [110]). Likewise, possible age, individual, or sociocultural differences should be considered in the need for space. Providing comfortable furniture and spaces, e.g., sofa groups and cushions (sub-studies 2 and $3 ;[8,65]$ is likely to foster physical ease in learning environments. Excessive comfort may, however, be unergonomic and even detrimental to learning $[16,17]$. This calls for the design carefully balancing comfort with health.

Principle 8: Design pleasant environments.

Principle 8.1: Design aesthetically pleasant spaces. It is important to pay attention to aesthetic interior design and colours (sub-studies 1-3; $[7,10,46])$, e.g., by balancing colours that are stimulating, fresh, or not depressing, with calming, not disturbing colours or by colour-changing lamps so as to vary colours (sub-study 3 ).

Principle 8.2: Design for control of light. It is important to ensure that spaces are luminous (sub-studies 1-3, [8]), e.g., by designing wide windows, glass surfaces, and good lighting (sub-study 3). Good artificial light control and quantity have been associated to better learning outcomes [16]. Further, the need for good artificial light design is likely to be more important in geographical areas such as Finland with shorter periods of daylight during the winter.

Principle 8.3: Design spaces entailing elements of nature. Learning environments should include elements of nature (sub-studies 1-3; [11,16]), e.g., gardens, park areas (substudies 1 and 2) and interior plants (sub-study 3). Natural environment can also be seen to entail daylight, connection of the classroom with the outside, and natural ventilation [17]. There may also be more need to focus on the presence of nature in highly urban areas in comparison to areas that are exposed to nature.

\subsection{Health}

Principle 9: Design environments promoting physical wellness.

Principle 9.1: Provide high quality meals. Physical wellness may be nurtured by the healthy and tasty school meal (sub-study 2; [46]). Literature [11,104] supports the importance of paying attention to the type and quality of school canteen and catering, having sufficient time for eating, and access to water.

Principle 9.2: Design for good indoor air quality and temperature. It is important to pay attention to optimal indoor air quality (sub-studies 2 and 3; [20]) and temperature (substudy $3 ;[42,111])$. In countries such as Finland with long winters and low temperatures, good insulation and heating is an important requirement. In warmer countries such as Spain, in turn, there may be a need to focus on preventing overheating but also extreme cold, e.g., due to manual window-airing in the cold season [16].

Principle 9.3: Provide opportunities for exercise, play, and hanging out with peers. Good outdoor environments (sub-study 2; [63]) and opportunities and spaces for physical exercise (sub-studies 1 and 2; [44]) are known to support physical wellness.

Principle 9.3: Design for good ergonomics. There is a need to consider good ergonomics and provide ergonomic furniture, e.g., adjustable desks and chairs (sub-study $3 ;[34,110])$. It is important to consider not only body measurements but also the adequacy of furniture ergonomics for different learning situations [16] such as teacher-led instruction and practical work.

Principle 10: Design environments that help to avoid overload.

Principle 10.1: Provide possibilities for rest and leisure time. Provide time and spaces for rest (sub-studies 1-3; $[43,65]$ ) and for more active recreation and leisure time (sub-studies 1-3; $[3,20,104])$. Separate leisure zones as well as loft beds, niches for quiet reflection, "caves" or shallower places under the stairs (see [81]) may be employed during the breaks. 


\subsection{Novelty}

Principle 11: Design environments with novel tools.

Principle 11.1: Design use of technological tools so that there is easy access to them and support needed for their use. It seems recommendable to use technology (sub-studies 1-3; [9]) together with support for teachers for their use (sub-study 3; [31]). Tanner [65] recommended that technological equipment be placed so that its use is easy to integrate with curriculum, teaching, and learning. Likewise, it is important to design and select technological tools based on the specific requirements of each educational level [14]. The layout of hardware and technical support materials should also be designed so that they do not limit the flexible use of spaces $[16,112,113]$. Attention should also be paid to issues such as the Wi-Fi coverage and the placement of sockets, power strips, and wires [14,16]. There may also be local differences in the quality of ICT infrastructure that need to be considered in the design and use of technology

Principle 11.2: Design educational elements to the spaces, indoor and outdoor. Educational design elements, e.g., planetarium ceiling, solar system model, or colour-changing lamps for teaching colour theory (sub-study 3 ) may be used so as to consider the whole school building as a tool for learning (see also $[63,104])$. Spaces with visible infrastructure provide a possibility to use the building structure as a learning tool [104] and walls may be used as display areas for subject material or products of research activity [63].

Principle 12: Design environments entailing novel spaces.

Principle 12.1: Promote informal learning. It is good to take advantage of informal, outside school environments and create connections between formal and informal learning (sub-studies 1 and 2; [9]). Novel mobile technology may also be used to augment physical spaces and expand activities outside the classroom [85].

Principle 12.2: Foster inspiration and motivation. It seems beneficial to design spaces with novel, inspiring, and motivating interior design (sub-study 3; [7]) with exciting and surprising elements such as different textures, shapes, or untraditional furniture. There should be "an atmosphere of excitement for learning" ([65], p. 453). The importance of novel, inspiring, and motivating environments is also supported by studies highlighting the importance of satisfaction, joy, and happiness for student learning and wellbeing $[6,8,109]$.

\subsection{Conventionality}

Principle 13: Design environments allowing the use of conventional tools.

Principle 13.1: Design by building on tradition. Instead of abandoning books and other traditional materials (sub-studies 1-3; [8]), it is recommended to balance novel tools and, e.g., computer access with adequate space for books and other non-digital learning materials [34].

Principle 13.1: Design for sustainability as a model for others. It is important to consider sustainability in the design (sub-study 2; [46]). As recommended by Nuikkinen [38], the school building can serve as a physical model of ecologically, economically, socially, and culturally sustainable design.

Principle 14: Design environments including conventional spaces.

Principle 14.1: Provide opportunities to integrate non-formal and formal learning. Attention should be paid to creating connections between non-formal learning environments, e.g., libraries, museums, science centres, and formal learning environments, e.g., classrooms (sub-studies 1 and 2; [8]).

Principle 14.2: Respect conventions. Conventional design, but also spaces that retain reversibility or convertibility to the traditional classroom may satisfy both learner-centred and traditional, teacher-led instruction (sub-studies 1-3; [32]). As Frelin and Grannas [81] remind us, chance does not necessarily mean improvement: well-functioning arrangements should not be abandoned only for the sake of change.

\subsection{Flexibility and Functionality}

Principle 15: Design flexible environments with high functionality. 
Principle 15.1: Design versatile environments. It is important to employ versatile tools and materials and versatile methods (sub-studies 1-3), supported e.g., by varying learning stations both inside and outside the classroom (sub-study 3). Learner-centred activities such as presentations; large, medium, or small interactive activities; creative work (e.g., art, laboratory); and reflection (reading, writing, research) require a wide range of different spaces: classrooms, commons, meeting areas, fixed areas, spaces for outdoor learning, and so on [32].

Principle 15.2: Ensure that environments are adaptable, functional, and practical. There is a need for adaptable, functional, and practical tools, spaces, and ways of working that can be easily modified, e.g., furniture allowing multiple configurations (sub-study 3) and adapting the learning environment design in accordance with context-specific requirements (sub-studies 1-3). There is also a need for fluidity or adaptability, i.e., the space capacity or agility for flow and change between activities [32]. It is important also to support adaptation to, e.g., open and flexible learning environments [112]. All members of the learning community need to be supported in the transition to innovative learning environments [81] in order to assure their functionality and practicality.

\section{Limitations and Future Directions}

This study focused on shared perceptions of learners representing different sociocultural contexts, ages, and educational levels with the aim of constructing a generic design framework and principles which considers learners' perceptions and is also supported by the literature. There are, however, differences between contexts as well as purposes of spaces (e.g., classroom, art class, laboratory) that need to be considered when applying these principles in the learning environment design (see also $[14,16,17])$. As stated by Veloso and Marques ([113], p. 246), it is important to consider "the specific needs of the schools, such as its organisational, social environment, space uses, and learning aims". As proposed by Woolner and Cardellino ([114], p. 14), PD can be seen as a way to avoid excessive generalisation or "uncritical transfer of practices, curricula, and school buildings between differing contexts". We encourage, however, to also use the LED framework to reflect if there are some challenges in the context that should be tackled. In this way, the co-design can lead to changes in the existing context, instead of only adapting the design into the context.

While this study focused on shared views, some differences were also identified. Particularly in sub-study 3 focusing on the co-design of natural science learning spaces with upper secondary school students, various new characteristics emerged. In addition to focusing on a specific type of space, it is also likely that older learners were more aware and able to express particularly more abstract ideas related to their learning environment preferences. It is, indeed, important to adapt co-design goals and methods to participants age and educational context. In future studies, more attention could be given to identify the contextual differences that need to be considered in the design in order to respond to specific needs of each learning community.

It is also good to bear in mind that the LED framework synthesising a wide range of characteristics conducive to learning and wellbeing is limited in its capacity to consider each characteristic individually. For example, within the subtheme "teaching-learning interaction" or "individualisation", there could be a long list of activities that could be employed in learning situations. We think that the role of the LED framework is to provide general directions, which can then be specified in each co-design process.

This study did not focus on interrelations or dependencies between different learning environment characteristics, nor did it measure the impact of these characteristics on learning outcomes (cf. [7,15-18]). In addition to focusing on interrelations between various characteristics or their effects on learning outcomes, in the future, it would be interesting to collect wellbeing data, e.g., by means of wearable sensors (see [115]) in order to evaluate the impact of learning environments on wellbeing, for instance, balance between stress and recovery during the day. 
Furthermore, the framework presented in this article focuses particularly on the learner perceptions. In future research, the aim is to employ and further develop the framework in a learning environment co-design with teachers. There is also need to facilitate collaboration between teachers contributing pedagogical ideas and, e.g., interior architects contributing to comfort, work stations, furniture, and so on [81]. Views of other internal stakeholders such as non-teaching staff should also be considered [114].

The aim is also to adapt the framework to early childhood and higher education. Furthermore, the COVID-19 pandemic has brought to light various challenges that need to be addressed in the learning environment design, particularly related to remote learning in home environments but also to needs such as enabling a safe distance in face-to-face learning situations. In the future studies, the aim is also to ensure that the LED framework responds to the design of hybrid or blended learning environments.

\section{Conclusions}

This study responded to the need to create both theoretically and practically significant design framework and principles gathering psychosocial and technology-enhanced physical and virtual learning environment characteristics fostering learning and wellbeing. The focus was particularly on ensuring that characteristics relevant for learners are considered in the framework. As a new, both theoretical and practical contribution, in comparison to earlier models, particularly the need for balancing and reaching the equilibrium between varying needs and preferences is now more strongly emphasised.

The empirically and theoretically grounded LED framework and principles developed in this study can be used for planning, gathering information, classifying data, and structuring the evaluation of individual co-design initiatives. The framework can be used as a check-list guiding design research and in organizing co-design workshops with stakeholders. The seven constructs of the framework are interlinked and should all be discussed and dealt concurrently in relation to each other. The design framework and principles may help designers in the design process to recognise design opportunities, challenges, and constraints. They can serve as a research-based introduction to the topic after which priorities can be defined based on the concrete design target and goals and concrete design solutions can be created in the co-design sessions.

In addition to individual co-design initiatives, the LED framework and principles can be used to compare and generalise findings between different learning environment co-design projects. In each co-design case, depending on the target, some characteristics are expected to be confirmed as relevant while some may not. It is also possible that some new characteristics, that could be added to the framework, emerge. We view, however, that the LED framework and principles can serve as a research-based starting point creating awareness of the issues identified as important in international body of literature. After that, PD efforts are made to concretise the contextual needs and design decisions.

Author Contributions: Conceptualization, T.M. and T.L.; methodology, T.M.; formal analysis, T.M.; investigation, T.M.; resources, T.M.; data curation, T.M.; writing-original draft preparation, T.M. and T.L.; visualization, T.M. and T.L.; project administration, T.M.; funding acquisition, T.M. All authors have read and agreed to the published version of the manuscript.

Funding: The research was funded by the Finnish Funding Agency for Technology and Innovation through the Indoor Environment Program (2011-2014), the Finnish Cultural Foundation's Central Finland Regional Fund (2013-2018), and the Finnish Foundation for Municipal Development (2020-22).

Institutional Review Board Statement: The study was conducted according to the guidelines of the Declaration of Helsinki and Finnish Advisory Board on Research Integrity, and instructed by the University of Jyväskylä Ethical Commitee. Only information on participants' gender, age, nationality, and school was asked without linking any other personal data to responses. For this reason, there was no need for an additional Institutional Review Board Statement.

Informed Consent Statement: Informed consent was obtained from all subjects involved in the study. Also parental consent was obtained from participants under 18 years old. 
Data Availability Statement: The datasets used and analysed during in the study are available in original languages from the corresponding author on reasonable request.

Acknowledgments: We are especially grateful to school directors, teachers, and learners as well as various designers, researchers, and research assistants contributing and participating in the study.

Conflicts of Interest: The authors declare no conflict of interest. The funders had no role in the design of the study; in the collection, analyses, or interpretation of data; in the writing of the manuscript, or in the decision to publish the results.

\section{References}

1. Organisation for Economic Co-operation and Development (OECD). Available online: https://www.oecd.org/education/ effective-learning-environments / (accessed on 23 November 2021).

2. Fraser, B.J. Classroom Environment Instruments: Development, validity and applications. Learn. Environ. Res. 1998, 1, 7-33. [CrossRef]

3. Konu, A.; Rimpelä, M. Well-being in schools: A conceptual model. Health Promot. Int. 2002, 17, 79-87. [CrossRef]

4. Horne Martin, S. The Classroom Environment and its Effects on the Practice of Teachers. J. Environ. Psychol. 2002, 22, 139-156. [CrossRef]

5. Cleveland, B.; Fisher, K. The Evaluation of Physical Learning Environments: A Critical Review of the Literature. Learn. Environ. Res. 2014, 17, 1-28. [CrossRef]

6. Awartani, M.; Whitman, C.V.; Gordon, J. Developing Instruments to Capture Young People's Perceptions of How School as a Learning Environment Affects of Their Well-Being. Eur. J. Educ. 2008, 43, 51-70. [CrossRef]

7. Barrett, P.; Zhang, Y.; Moffat, J.; Kobbacy, K. A Holistic, Multi-level Analysis Identifying the Impact of Classroom Design on Pupils' Learning. Build. Environ. 2013, 59, 678-689. [CrossRef]

8. Kangas, M. Finnish Children's Views on the Ideal School and Learning Environment. Learn. Environ. Res. 2010, 13, 205-223. [CrossRef]

9. Kuuskorpi, M. Tulevaisuuden Fyysinen Oppimisympäristö. Käyttäjälähtöinen Muunneltava ja Joustava Oppimistila. (Future Physical Learning Environment. User Oriented Flexible and Changeable Teaching Spaces). Doctoral Thesis, Education University of Turku Faculty of Education, Turku, Finland, 2012.

10. Ghaziani, R. School Design: Researching children's views. Child. Today 2010, 4, 1-27.

11. Ghaziani, R. An Emerging Framework for School Design Based on Children's Voices. Child. Youth Environ. 2012, 22, 125-144. [CrossRef]

12. Gislason, N. Architectural Design and the Learning Environment: A framework for school design Research. Learn. Environ. Res. 2010, 13, 127-145. [CrossRef]

13. Byers, T.; Imms, W.; Hartnell-Young, E. Evaluating teacher and student spatial transition from a traditional classroom to an innovative learning environment. Stud. Educ. Eval. 2018, 58, 156-166. [CrossRef]

14. López Costa, M. The integration of digital devices into learning spaces according to the needs of primary and secondary teachers. TEM J. 2019, 8, 1351-1358.

15. Barrett, P.; Davies, F.; Zhang, Y.; Barrett, L. The holistic impact of classroom spaces on learning in specific subjects. Environ. Behav. 2017, 49, 425-451. [CrossRef] [PubMed]

16. López-Chao, V.; López-Pena, V. Purpose Adequacy as a Basis for Sustainable Building Design: A Post-Occupancy Evaluation of Higher Education Classrooms. Sustainability 2021, 13, 11181. [CrossRef]

17. López-Chao, V.; Amado Lorenzo, A.; Saorín, J.L.; La Torre-Cantero, D.; Melián-Díaz, D. Classroom Indoor Environment Assessment through Architectural Analysis for the Design of Efficient Schools. Sustainability 2020, 12, 2020. [CrossRef]

18. López-Chao, V.; Lorenzo, A.A.; Martin-Gutiérrez, J. Architectural indoor analysis: A holistic approach to understand the relation of higher education classrooms and academic performance. Sustainability 2019, 11, 6558. [CrossRef]

19. Cornelius-White, J.D. Learner-centered teacher-student relationships are effective: A meta-analysis. Rev. Educ. Res. 2007, 77, 113-143. [CrossRef]

20. Kostenius, C. Picture This-Our Dream School! Swedish school children sharing their visions of School. Childhood 2011, 18, 509-525. [CrossRef]

21. Smith, R.C.; Iversen, O.S. Participatory design for sustainable social change. Des. Stud. 2018, 59, 9-36. [CrossRef]

22. Mäkelä, T.; Kankaanranta, M.; Helfenstein, S. Considering Learners' Perceptions in Designing Effective 21st Century Learning Environments for Basic Education in Finland. Int. J. Educ. Organ. Leadersh. 2014, 20, 1-13. [CrossRef]

23. Mäkelä, T.; Helfenstein, S. Developing a conceptual framework for participatory design of psychosocial and physical learning environments. Learn. Environ. Res. 2016, 19, 411-440. [CrossRef]

24. Mäkelä, T.; Helfenstein, S.; Lerkkanen, M.-K.; Poikkeus, A.-M. Student participation in learning environment improvement: Analysis of a co-design project in a Finnish upper secondary school. Learn. Environ. Res. 2018, 21, 19-41. [CrossRef]

25. Mäkelä, T. A Design Framework and Principles for Co-Designing Learning Environments Fostering Learning and Wellbeing: Jyväskylä, Finland: University of Jyväskylä. Jyväskylä Studies in Education, Psychology and Social Research. 2018, p. 603. 
Available online: https:/ / www.jyu.fi/edupsy/fi/tohtorikoulu/kasvatustieteiden-tohtoriohjelma/valmistuneet-vaitoskirjat/ makela_tiina_vaitoskirja.pdf (accessed on 23 November 2021).

26. Dewey, J. The School and Society; University of Chicago Press: Chicago, IL, USA, 1907.

27. Dewey, J. Democracy and Education: An Introduction to the Philosophy of Education; Electronic Version by the University of Virginia American Studies Program 2003. 1916. Available online: https://www.gutenberg.org/cache/epub/852/pg852-images. html (accessed on 23 November 2021).

28. Cohen, J. Social, Emotional, Ethical, and Academic Education: Creating a climate for learning, participation in democracy, and well-being. Harv. Educ. Rev. 2006, 76, 201-237. [CrossRef]

29. Vygotsky, L.S. Mind in Society. In The Development of Higher Psychological Processes; Cole, M., Ed.; Harvard University Press: Cambridge, MA, USA, 1978.

30. Bronfenbrenner, U. The Ecology of Human Development; Harvard University Press: Cambridge, MA, USA, 1979.

31. Fisher, K.; Newton, C. Transforming the twenty-first-century campus to enhance the net-generation student learning experience: Using evidence-based design to determine what works and why in virtual/physical teaching spaces. High. Educ. Res. Dev. 2014, 33, 903-920. [CrossRef]

32. Dovey, K.; Fisher, K. Designing for adaptation: The school as socio-spatial assemblage. J. Archit. 2014, 19, 43-63. [CrossRef]

33. Monahan, T. Flexible space build pedagogy: Emerging IT embodiments. Inventio 2002, 4, 1-19.

34. Zandvliet, D.B.; Fraser, B.J. Physical and Psychosocial Environments Associated with Networked Classrooms. Learn. Environ. Res. 2005, 8, 1-17. [CrossRef]

35. Luck, R. Design research, architectural research, architectural design research: An argument on disciplinarity and identity. Des. Stud. 2019, 65, 152-166. [CrossRef]

36. Bronfenbrenner, U. Ecological models of human development. In International Encyclopaedia of Education, 2nd ed.; Elsevier: Oxford, UK, 1994; Volume 3, pp. 37-43.

37. Wang, M.-T.; Holcombe, R. Adolescents' Perceptions of School Environment, Engagement, and Academic Achievement in Middle School. Am. Educ. Res. J. 2010, 47, 633-662. [CrossRef]

38. Nuikkinen, K. Koulurakennus ja hyvinvointi. Teoriaa ja Käytännön Kokemuksia Peruskouluarkkitehtuurista (School Building and Well-Being. Theory and Practical Experiences of School Architecture). Doctoral Dissertation, Tampere University, Tampere, Finland, 2009; p. 1398.

39. Spilt, J.L.; Koomen, H.M.; Thijs, J.T. Teacher wellbeing: The importance of teacher-student relationships. Educ. Psychol. Rev. 2011, 23, 457-477. [CrossRef]

40. den Besten, O.; Horton, J.; Kraftl, P. Pupil involvement in school (re)design: Participation in policy and practice. Int. J. CoCreation Des. Arts 2008, 4, 197-210. [CrossRef]

41. Saaranen, T.; Sormunen, M.; Pertel, T.; Streimann, K.; Hansen, S.; Varava, L.; Lepp, K.; Turunen, H.; Tossavainen, K. The occupational well-being of school staff and maintenance of their ability to work in Finland and Estonia-Focus on the school community and professional competence. Health Educ. 2012, 112, 236-255. [CrossRef]

42. Crespo, J.; Pino, M. Description of Environmental Factors in Schools: Lessons from a study in North-west Spain. Rev. Educ. 2007, 53, 205-218.

43. Pellegrini, A.D.; Bohn, C.M. The role of recess in children's cognitive performance and school adjustment. Educ. Res. 2005, 34, 13-19. [CrossRef]

44. Papatheodorou, T. How We Like Our School to Be ... Pupils' Voices. Eur. Educ. Res. J. 2002, 1, 445-467. [CrossRef]

45. Fox, K.R.; Cooper, A.; McKenna, J. The School and Promotion of Children's Health-Enhancing Physical Activity: Perspectives from the United Kingdom. J. Teach. Phys. Educ. 2004, 23, 338-358. [CrossRef]

46. Piispanen, M. Good Learning Environment. Perceptions of Good Quality in Comprehensive School by Pupils, Parents and Teachers; University of Jyväskylä, Kokkola University Consortium Chydenius: Jyväskylä, Finland, 2008.

47. Thorburn, M.; MacAllister, J. Dewey, Interest, and Well-being: Prospects for Improving the Educational Value of Physical Education. Quest 2013, 65, 458-468. [CrossRef]

48. Atjonen, P.; Korkeakoski, E.; Mehtäläinen, J. Key pedagogical principles and their major obstacles as perceived by comprehensive school teachers. Teach. Teach. Theory Pract. 2011, 17, 273-288. [CrossRef]

49. Elen, J.; Clarebout, G.; Léonard, R.; Lowyck, J. Learner-centred and Teacher-centered Learning Environments: What students think. Teach. High. Educ. 2007, 12, 105-117. [CrossRef]

50. Epstein, J.L.; Sheldon, S.B. Moving forward: Ideas for research on school, family, and community partnerships. In $S A G E$ Handbook for Research in Education: Engaging Ideas and Enriching Inquiry; SAGE Publications, Inc.: Thousand Oaks, CA, USA, 2006; pp. 117-138.

51. Kirschner, P.A.; Sweller, J.; Clark, R.E. Why minimal guidance during instruction does not work: An analysis of the failure of constructivist, discovery, problem-based, experiential, and inquiry-based teaching. Educ. Psychol. 2006, 41, 75-86. [CrossRef]

52. Loyens, S.M.; Magda, J.; Rikers, R.M. Self-directed learning in problem-based learning and its relationships with self-regulated learning. Educ. Psychol. Rev. 2008, 20, 411-427. [CrossRef]

53. Ryan, R.M.; Deci, E.L. Deci Self-determination theory and the facilitation of intrinsic motivation, social development, and well-being. Am. Psychol. 2000, 55, 68-78. [CrossRef] [PubMed] 
54. Linnankylä, P.; Malin, A. Finnish Students' School Engagement in the Light of PISA 2003. Scand. J. Educ. Res. 2008, 52, 583-602. [CrossRef]

55. Lewis, A.E.; Forman, T.A. Contestation or collaboration? A comparative study of home-school relations. Anthropol. Educ. Q. 2002, 33, 60-89. [CrossRef]

56. Lowyck, J.; Pöysä, J. Design of collaborative learning environments. Comput. Hum. Behav. 2001, 17, 507-516. [CrossRef]

57. Laal, M.; Ghodsi, S.M. Benefits of collaborative learning. Procedia-Soc. Behav. Sci. 2012, 31, 486-490. [CrossRef]

58. Brown, S. Assessment for learning. Learn. Teach. High. Educ. 2005, 1, 81-89.

59. Hargreaves, D. Personalising Learning: Next Steps in Working Laterally; Specialist Schools Trust: London, UK, 2004.

60. Scardamalia, M.; Bransford, J.; Kozma, B.; Quellmalz, E.E. New Assessment and Environments for Knowledge Building. In Assessment and Teaching of 21st Century Skills; Griffin, P., McGaw, B., Care, E., Eds.; Springer: Dordrecht, The Netherlands, 2012.

61. Kuuskorpi, M.; Cabellos, N. The Future of the Physical Learning Environment. School Facilities that Support the User. In Learning Environment Exchange, Centre for Effective Learning Environments, 2011/11; OECD Publishing: Paris, France, 2011.

62. Kukk, A.; Talts, L. Teachers' self-assessment of their professional skills according to the Teachers' Professional Standard. J. Teach. Educ. Sustain. 2007, 8, 14. [CrossRef]

63. Jamieson, P.; Fisher, K.; Gildings, T.; Taylor, P.G.; Trevitt, A.C.F. Place and Space in the Design of New Learning Environments. High. Educ. Res. Dev. 2000, 19, 221-237. [CrossRef]

64. Sanoff, H. A Visioning Process for Designing Responsive Schools; National Clearinghouse for Educational Facilities (NCEF): Washington, DC, USA, 2001.

65. Tanner, K.C. Explaining Relationships Among Student Outcomes and the School's Physical Environment. J. Adv. Acad. 2008, 19, 444-471. [CrossRef]

66. Alexander, K. Usability of learning environments. In CIB W111: Usability Workplaces-Phase; International Council for Research and Innovation in Building and Construction CIB General Secretariat: Rotterdam, The Netherlands, 2010; Phase 3; p. 5.

67. Duca, G. Usability requirements for buildings: A case study on primary schools. Work 2012, 41 (Suppl. 1), 1441-1448. [CrossRef]

68. van den Akker, J. Curriculum Design Research. In An Introduction to Educational Design Research; Plomp, T., Nieveen, N., Eds.; SLO: Enschede, The Netherlands, 2007; pp. 37-50.

69. Brown, A.L. Design Experiments: Theoretical and methodological challenges in creating complex interventions in classroom settings. J. Learn. Sci. 1992, 2, 141-178. [CrossRef]

70. Cobb, P.; Confrey, J.; Disessa, A.; Lehrer, R.; Schauble, L. Design Experiments in Educational Research. Educ. Res. 2003, 32, 9-13. [CrossRef]

71. Richey, R.C.; Klein, J.D.; Nelson, W.A. Developmental Research: Studies of instructional design and development. In Handbook of Research for Educational Communications and Technology, 2nd ed.; Jonassen, D., Ed.; Lawrence Erlbaum: Mahwah, NJ, USA, 2004; pp. 1099-1130.

72. The Design-Based Research Collective. Design-Based Research: An Emerging Paradigm for Educational Inquiry. Educ. Res. 2003, 32, 5-8. [CrossRef]

73. Oh, E.; Reeves, T.C. The Implications of the Differences between Design Research and Instructional Systems Design for Educational Technology Researchers and Practitioners. Educ. Media Int. 2010, 47, 236-275. [CrossRef]

74. Barab, S.; Squire, K. Design-Based Research: Putting a Stake in the Ground. J. Learn. Sci. 2004, 13, 1-14. [CrossRef]

75. Collins, A.; Joseph, D.; Bielaczyc, K. Design Research: Theoretical and Methodological Issues. J. Learn. Sci. 2004, 13, 15-42. [CrossRef]

76. Anderson, T.; Shattuck, J. Design-Based Research: A Decade of Progress in Education Research? Educ. Res. 2012, 41, 16-25. [CrossRef]

77. $\quad$ van den Akker, J.; Branch, R.M.; Gustafson, K.; Nieveen, N.; Plomp, T. Design Approaches and Tools in Education and Training; van den Akker, J., Branch, R.M., Gustafson, K., Nieveen, N., Plomp, T., Eds.; Kluwer Academic: Boston, MA, USA, 1999 ; pp. 1-14.

78. Edelson, D.C. Design Research: What We Learn When We Engage in Design. J. Learn. Sci. 2002, 11, 105-121. [CrossRef]

79. Bell, P. On the Theoretical Breadth of Design-Based Research in Education. Educ. Psychol. 2004, 39, 243-253. [CrossRef]

80. Wang, F.; Hannafin, M.J. Design-based Research and Technology-Enhanced Learning Environments. Educ. Technol. Res. Dev. 2005, 53, 5-23. [CrossRef]

81. Frelin, A.; Grannäs, J. Designing and Building Robust Innovative Learning Environments. Buildings 2021, 11, 345. [CrossRef]

82. Newman, M.; Thomas, P. Student Participation in School Design: One School's Approach to Student Engagement in the BSF Process. Int. J. CoCreation Des. Arts 2008, 4, 237-251. [CrossRef]

83. Woolner, P.; Hall, E.; Wall, K.; Dennison, D. Getting together to improve the school environment: User consultation, participatory design and student voice. Improv. Sch. 2007, 10, 233-248. [CrossRef]

84. Könings, K.D.; van Zundert, M.; Brand-Gruwel, S.; van Merriënboer, J.J.G. Participatory Design in Secondary Education: Is it a Good Idea? Students' and Teachers' Opinions on its Desirability and Feasibility. Educ. Stud. 2007, 33, 445-465. [CrossRef]

85. Leinonen, T.; Keune, A.; Veermans, M.; Toikkanen, T. Mobile Apps for Reflection in Learning: A Design Research in K-12 Education. Br. J. Educ. Technol. 2016, 47, 184-202. [CrossRef]

86. Könings, K.D.; Brand-Gruwel, S.; van Merriënboer, J.J.G. Towards More Powerful Learning Environments Through Combining the Perspectives of Designers, Teachers, and Students. Br. J. Educ. Psychol. 2005, 75, 645-660. [CrossRef] 
87. Woolner, P. Building schools for the future through a participatory design process: Exploring the issues and investigating ways forward. In Proceedings of the BERA 2009, Manchester, UK, 2-5 September 2009.

88. Parnell, R.; Cave, V.; Torrington, J. School Design: Opportunities Through Collaboration. Int. J. CoCreation Des. Arts 2008, 4, 211-224. [CrossRef]

89. Fielding, M. Transformative approaches to student voice: Theoretical underpinnings, recalcitrant realities. Br. Educ. Res. J. 2004, 30, 295-311. [CrossRef]

90. Frost, R.; Holden, G. Student voice and future schools: Building partnerships for student participation. Improv. Sch. 2008, 11, 83-95. [CrossRef]

91. Lodge, C. From hearing voices to engaging in dialogue: Problematising student participation in school improvement. J. Educ. Chang. 2005, 6, 125-146. [CrossRef]

92. Robinson, C.; Taylor, C. Student voice as a contested practice: Power and participation in two student voice projects. Improv. Sch. 2012, 16, 32-46. [CrossRef]

93. Sanders, E.B.N.; Stappers, P.J. Co-creation and the new landscapes of design. Int. J. CoCreation Des. Arts 2008, 4, 5-18. [CrossRef]

94. Simmons, C.; Graham, A.; Thomas, N. Imagining an ideal school for wellbeing: Locating student voice. J. Educ. Chang. 2015, 16, 129-144. [CrossRef]

95. Woolner, P.; McCarter, S.; Wall, K.; Higgins, S. Changed learning through changed space: When can a participatory approach to the learning environment challenge preconceptions and alter practice? Improv. Sch. 2012, 15, 45-60. [CrossRef]

96. Selwyn, N.; Boraschi, D.; Özcula, S.M. Drawing digital pictures: And investigation of primary pupils' representations of ICT and schools. Br. Educ. Res. J. 2009, 35, 909-928. [CrossRef]

97. Woolner, P.; Clark, J.; Hall, E.; Tiplady, L.; Thomas, U.; Wall, K. Pictures Are Necessary but Not Sufficient: Using a range of visual methods to engage users about school design. Learn. Environ. Res. 2010, 10, 1-22. [CrossRef]

98. Cam Aktas, B. Investigating Primary School Students' Perceptions Regarding 'Teacher' Through Their Drawings. Int. J. Learn. 2010, 17, 408-425.

99. Horelli, L. A Methodological Approach to Children's Participation in Urban Planning. Scand. Hous. Plan. Res. 1997, 14, 105-115. [CrossRef]

100. Mäkelä, T. A Design Framework and Principles for Co-designing Learning Environments Fostering Learning and Wellbeing. Learn. Des. 2018, 27 (Supplement: Dialogues 02), 10-11.

101. Moos, R.H. Person-Environment Congruence in Work, School, and Health Care Settings. J. Vocat. Behav. 1987, 31, 231-247. [CrossRef]

102. Gee, L. Human-Centered Design Guidelines. In Learning Spaces; Oblinger, D.G., Ed.; Educause: Washington, DC, USA, 2006.

103. Sulonen, J.; Sulonen, K. The Grammar of a Modern School Building. A comparative study on schools and the changing ways of learning. In Perspectives from Finland-Towards New Learning Environments; Kuuskorpi, M., Ed.; National Board of Education: Tampere, Finland, 2014.

104. Wolff, S.J. Design Features for Project-Based Learning; Oregon State University: Corvallis, OR, USA, 2002.

105. Kudlats, J.; Brown, K.M. Knowing Kids Makes a Huge Difference, Part II: Advancing a Conceptual Framework for Positive Principal-Student Relationships. J. Sch. Leadersh. 2020, 31, 451-477. [CrossRef]

106. Sandström, N.; Ketonen, E.; Lonka, K. The Experience of Laboratory Learning-How Do Chemistry Students Perceive Their Learning Environment? Soc. Behav. Sci. 2014, 11, 1612-1625. [CrossRef]

107. Sjöblom, K.; Mälkki, K.; Sanström, N.; Lonka, K. Does Physical Environment Contribute to Basic Psychological Needs? A Self-Determination Theory Perspective on Learning in the Chemistry Laboratory. Frontline Learn. Res. 2016, 4, 17-39. [CrossRef]

108. Higgins, S.; Hall, E.; Wall, K.; Woolner, P.; McCaughey, C. The Impact of School Environments: A Literature Review; Design Council: London, UK, 2005.

109. Flutter, J. 'This place could help you learn': Student participation in creating better school environments. Educ. Rev. 2006, 58, 183-193. [CrossRef]

110. Attai, S.L.; Reyes, J.C.; Davis, J.L.; York, J.; Ranney, K.; Hyde, T.W. Investigating the impact of flexible furniture in the elementary classroom. Learn. Environ. Res. 2021, 24, 153-167. [CrossRef]

111. Marchand, G.C.; Nardi, N.M.; Reynolds, D.; Pamoukov, S. The Impact of the Classroom Built Environment on Student Perceptions and Learning. J. Environ. Psychol. 2014, 40, 187-197. [CrossRef]

112. Niemi, K. 'The best guess for the future?' Teachers' adaptation to open and flexible learning environments in Finland. Educ. Inq. 2020, 12, 282-300. [CrossRef]

113. Veloso, L.; Marques, J.S. Designing science laboratories: Learning environments, school architecture and teaching and learning models. Learn. Environ. Res. 2017, 20, 221-248. [CrossRef]

114. Woolner, P.; Cardellino, P. Crossing Contexts: Applying a System for Collaborative Investigation of School Space to Inform Design Decisions in Contrasting Settings. Buildings 2021, 11, 496. [CrossRef]

115. Moilanen, H.; Äyrämö, S.; Jauhiainen, S.; Kankaanranta, M. Collecting and Using Students' Digital Well-Being Data in Multidisciplinary Teaching. Educ. Res. Int. 2018, 2018, 3012079. [CrossRef] 